\title{
Illiberalism as Constitutional Identity - the Case of Hungary
}

\begin{abstract}
ANDRÁS LÁSZLÓ PAP*
Abstract. The article consists of a thought experiment involving the modeling and conceptually positioning of the new political community and the political (theoretical) and constitutional construct that Prime Minister Orbán claims to have created and institutionalized through a new constitution in Hungary. Two concepts are at the center of the analysis: the contours, organizational foundations and defining features of the self-proclaimed new political community and the morphology and consequences of the illiberal nature of the newly established regime. The author argues that the Orbán government's self-proclaimed revolutionary regime claims, to have reconstituted and re-conceptualized the relationship between the state and its citizens, both in institutional and normative terms and 'illiberalism' is a form of constitutional identity guiding the discursive framework of this new political community. Keywords: illiberalism, constitutional identity, Fundamental Law, System of National Cooperation
\end{abstract}

\section{INTRODUCTION}

This article ${ }^{1}$ consists of a thought experiment involving the modeling and conceptually positioning of the new political community and the political (theoretical) and constitutional construct that Prime Minister Orbán claims to have created and institutionalized through a new constitution in Hungary. The methodology is a textual analysis of legal and constitutional documents, juxtaposed with political statements and declarations by the grand architect himself Mr. Orbán i.e., the self-assessment of the 'design' and the designer. Two concepts are at the center of the analysis: the contours, organizational foundations and defining features of the self-proclaimed new political community and the morphology and consequences of the illiberal nature of the newly established regime. In most cases, constitutional and political regimes do not self-identify as illiberal (or even as liberal) This is the work of analysts and academics. In this case, Prime Minister Orbán, with a quite unique declaration has done the work for them. However, there will be no authentic, first hand definitions found for the details and precise circumcision of the specificities of the newly emerged political community and source of legitimacy or the actual nature and role of illiberalism. These are the questions that this thought experiment will try to answer.

It must be noted that there is a multilayered intellectual and ethical dilemma within this process and it is one that the Author too has been struggling with it. First, there is the classic problem of analyzing legal and constitutional documents. These texts are almost always the outcomes of political compromises, rather than consensus and there is rarely a fully coherent philosophical or conceptual framework behind legislative solutions.

* Research Chair, Hungarian Academy of Sciences Centre for Social Sciences Institute for Legal Studies, SASPRO-Marie Curie Fellow, Slovak Academy of Sciences Institute for Sociology, Professor, National Public Service University Faculty of Law Enforcement, email: pap.andras.laszlo@tk.mta.hu.

1 Parts and earlier versions of this article have been published in a monograph on democratic decline in Hungary. Pap (2017). The research project was partly financed from the SASPRO Programme. The research leading to these results has received funding from the People Programme (Marie Curie Actions) European Union's Seventh Framework Programme under REA grant agreement No. 609427. Research has been further co-funded by the Slovak Academy of Sciences. 
Ironically, academics and courts, especially those engaged in constitutional review, are bound to interpret these texts as doctrinally sound wholes and work with the presupposition that there is a coherent and compact theoretical framework.

It is even more troubling when there is a reason to believe that in reality, that there is an $a d$ hoc and even worse, sheer and empty political PR, behind the statements and declarations which serve as building blocks for modeling. It will be shown that 'illiberal democracy' and the emergence of a new political community the 'System of National Cooperation', both core ideas, heavily scrutinized within this essay, appear to be marketing products.

An analysis of official government and Fidesz-communications shows that the concept of illiberal democracy was introduced as new path for Hungary in a seminal speech by Prime Minister Orbán. This placed him in international media headlines and was completely abandoned and never mentioned again after the first wave of publicity and media discoursesetting subdued. The concept of the 'System of National Cooperation' had a similar fate. It was identified as the epiphany of the new political community legitimizing a new constitutional regime, which was solemnly declared in the form of a parliamentary resolution. It was the rhetorical centre of the government program and a government order made it mandatory to be displayed in all government facilities in Hungary. However, after October 2012, there has not been a single reference made to it in government sources, politicians' speeches or documents. This makes one skeptical of intellectual endeavors involving grand theoretical designs.

\section{TERMINOLOGY AND CONCEPTUALIZATION}

Fareed Zakaria, in his seminal essay, argues that liberalism, either as a conception of political liberty or as a doctrine about economic policy, does not necessarily coincide with democracy $^{2}$ and defines liberal democracy as a political system marked not only by free and fair elections, but also by rule of law, separation of powers and the protections of basic liberties of speech, assembly, religion and property. Scholarly discussions on definitions have burgeoned in the recent years. Rupnik and Zielonka ${ }^{3}$ and Collier and Levitsky ${ }^{4}$ argue that authors often qualify the term democracy by adding adjectives such as liberal (or illiberal), deliberative, representative, participatory, delegative, façade, direct (or indirect), electoral, hybrid, Western, Islamic, managed, ${ }^{5}$ et cetera. Others refer to electoral or competitive autocracies ${ }^{6}$.

Csillag and Szelényi, ${ }^{7}$ building on Huntington's ${ }^{8}$ recent analysis, which serves as a starting point for this assessment, define liberalism and democracy as two distinct dimensions of good governance, identifying 'liberalism' with separation of powers and the security of private property rights and 'democracy' as majoritarian rule. They do not explicitly define illiberal democracy but describe the features of the 'emergent illiberal post-communist systems' in political terms and claim that as long as democratic institutions

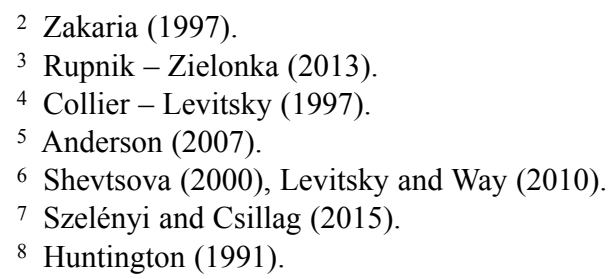


operate and leaders are elected to office, the ruling elites of these 'illiberal democracies need a legitimating ideology which can appeal to a broader electorate.' In their genealogy of 'post-communist managed illiberal democracy,' where property relations shift from private property and market capitalism to neo-patrimonial and eventually neo-prebendal property relations, they argue that the core distinguishing feature is this ideology - postcommunist traditionalist or neo-conservative. Gábor Halmai ${ }^{9}$ argues that under the standard political science definition for liberal democracy, the three independent but interconnected elements of democracy, human rights and the rule of law need to be simultaneously present. An illiberal regime, in contrast, is one where formal electoral democracy prevails but either or both of the other elements are missing, e.g., theocratic (Iran or Saudi-Arabia) or communitarian constitutions (South Korean or Taiwanese), which nevertheless retain a certain minimum level of constitutionalism. These, he argues, need to be distinguished from both autocratic regimes e.g., Putin's Russia, where there are opposition parties and even an independent press as these allow for the pretense of electoral competition, though in reality the opposition has no actual chance of winning an election and dictatorships e.g., the Soviet Union and the former communist countries or contemporary China, Vietnam, Cuba and Belarus, where there is neither an opposition nor an independent press so these cannot be considered constitutional regimes at all, even if formally speaking they happen to have written constitutions.

To avoid further entanglement in a conceptual and terminological labyrinth, throughout this volume 'illiberal' should be understood as a privative prefix, referring to a constitutional and political condition that creates a middle ground between a constitutional democracy and an autocracy. This reading is not unique in the literature. Csillag and Szelényi claim that the road from democracy to autocracy is paved with the 'stones' of illiberalism and while

illiberalism does not necessarily eliminate democracy, it creates conditions, given the weakness of Constitutional Courts and the legislative branch, for particularly powerful political leaders to flirt with abandoning democratic procedures if they may sense their electoral support eroded and they may not win the next elections. ${ }^{10}$

Bozóki' argues that the 'System of National Cooperation,' introduced by Prime Minister Viktor Orbán, which will be analyzed in detail in order to make the claim that it is one of the manifestations of the 'Hungarian illiberal democracy,' has emerged as an alternative to liberal democracy. In developing this interpretation, it will be argued that illiberalism in Hungary is a form of constitutional identity, a political discourse that creates the rhetorical and political framework for the newly constructed political community.

A note on populism is needed. Ádám and Bozóki's ${ }^{12}$ assessment ${ }^{13}$ that populism is an anti-elitist, anti-institutional political behavior that identifies with 'the people' and enhances their 'direct' participation in the political process as opposed to representative government, is very much accepted. Modern democratic populism in the post-WWII era can be

9 Halmai, link 8.

10 Szelényi and Csillag (2015).

11 Bozóki (2011).

12 Bozóki and Ádám (2016).

13 See Canovan (1999), Ionescu and Gellner (1969), Finchelstein (2014); Kriesi and Pappas (2015); Laclau (1987); Mudde, link 18., Shils (1956) and Urbinati (2014). 
interpreted as the substitute of totalitarian politics in the hegemony of democratic representation. Populism has an ideological character but, in itself, does not have a particular ideological content. It can be nationalistic, xenophobic, anti-feminist, anti-LGBT, antiliberal, anti-western, anti-Semitic, anti-Muslim or, even neoliberal. The main idea is that governing is based on popular participation with limited public contest for power. Thus, populism is truly 'democratic' even if it openly rejects the constitutional norms of liberal democracy - the only criterion is that populist political entrepreneurs perform top-down mass-mobilization. In populist governance, power is personalized and its execution is organized along personal relations. Formal political and administrative institutions need to be sufficiently fluid to allow for mass participation in politics, as 'simplification and polarization produce verticalization of political consent, which inaugurates a deeper unification of the masses under an organic narrative and a charismatic or Caesarist leader personating it." 14 The Author agrees with Zoltán and Bozóki's argument that 'populism should be seen as the political manifestation of illiberalism, especially in (semi-) peripheries such as Latin America and Eastern Europe,'15 and that in the Hungarian case, 'Fidesz managed to combine anti-elitism, nationalism and an anti-EU stance with a pragmatist approach in most policy areas, presenting a charismatic leadership, allegedly defending the national interest and those of ordinary people. ${ }^{16}$

\section{ILLIBERALISM AND THE EMERGENCE OF A NEW POLITICAL COMMUNITY: THE SYSTEM OF NATIONAL COOPERATION}

The starting point for Prime Minister Viktor Orbán's constitutional revolution was the 2010 Spring elections where a coalition of the Fidesz Party and the Christian Democratic Party, two self-identified right wing, conservative parties led by Fidesz-president Mr. Orbán, received $41.5 \%$ of all the people entitled to vote and $53.1 \%$ per cent of the actual votes cast which translated to $68 \%$ of the mandates in parliament. ${ }^{17}$ This gave the winners a two-third majority ${ }^{18}$ that allowed them to amend the constitution and organic laws, laws defined and enumerated by the constitution that also require a qualified, two-third majority of the votes

14 Bozóki and Ádám (2006) 100.

15 Bozóki and Ádám (2006) 115-16.

16 Bozóki and Ádám (2006) 100.

17 Kornai, link 16.

18 Hungary's electoral law combined three systems to elect the 386-member parliament: voting for single candidates from single-mandate district (SMD) contests (176 seats), voting for party lists in larger territorial districts using proportional rules to award seats (152 seats), and proportionally allocated compensation seats from national compensation lists (58 seats). The first two levels each required a ballot, while the national compensation list used 'surplus' votes not counted at the primary levels. In each SMD, candidates competed directly, and each voter chose her most preferred candidate on the ballot. If no candidate were to obtain more than half of the votes in a first round of voting, a run-off election was held two weeks later. The top three candidates and any candidate with more than 15 percent of the vote were to compete in the run-off election, in which the top vote-getter won the seat. In order to qualify as a candidate in any one of the 176 SMDs, the candidate must have collected so-called nomination slips from a minimum of 750 voters, each one signed by the voter personally. A party's success in qualifying individual candidates also affected its eligibility in the proportional list races of the territorial districts. For a party to be eligible to register a list of candidates for the territorial districts, the party must have had a certain minimum number (usually one quarter of the total individual seats in that district) of qualified single-mandate candidates (IRI, n.d.). 
in parliament. The newly elected government carried out a swift, and well documented, ${ }^{19}$ redesign of the constitutional landscape in Hungary.

On 28 June 2010, upon the proposal of a Fidesz MP, Parliament repealed Article 24 (5) of the Constitution which required a four-fifths majority of MPs to adopt the procedural rules of the preparation of a new Constitution. Thus, the governing coalition, having a twothirds majority, eliminated the provision obliging it to cooperate with opposition parties whilst preparing the new Constitution. A Parliamentary Ad Hoc Committee Preparing the Constitution was established on the same day. 30 out of its 45 were members of the governing coalition. The committee prepared a Concept Paper, which was only considered to be a working document. A Draft was prepared by Fidesz/Christian Democrat MPs and introduced to Parliament on 14 March 2011. The new constitution, known as the Fundamental Law was adopted on 18 April solely with the votes of the Fidesz/Christian Democrats coalition and entered into force on 1 January 2012. It has been the sole product of the governing political party and has been adopted by the governing majority without the support of any other political force. The text, widely criticized by national, European and international NGOs and organizations was adopted on the basis of a Bill submitted from 35 day-long debate and exclusively by the votes of members of the governing coalition. ${ }^{20}$

Orbán's regime claims no less than having created a new a political community. This is reflected for example in the changing the official name of the state from 'Magyar Köztársaság' to 'Magyarország.' The former, commonly referred to in English as the 'Republic of Hungary' in Hungarian, was actually 'Hungarian Republic,' a grammatical syntax with the noun 'republic' specified with the adjective 'Hungarian' ('magyar'). Magyarország ('Magyarstan') means 'Hungarian Country,' grammatically a morpheme, a complex word derived from the agglutination of the words 'Hungarian' ('magyar' - can be either a noun or an adjective) and 'Country' ('ország'). ${ }^{21}$ Border signage, passport cover pages and identity cards have all been changed and even courts deliver judgments in the name of the new subject.

The new political community was officially declared in a formally non-binding, unique pre-constitutional document, Political Declaration 1 of 2010 (16 th $\left.^{\text {thene }}\right)$ of the Hungarian Parliament on national cooperation. This document foresees and legitimizes a total break with the preexisting political community and declared the emergence of a new political community, the 'System of National Cooperation' (hereinafter SNC), which originates retroactively from a 'voting booth revolution,' a term used to describe the election which created the parliamentary supermajority of the governing coalition (Fidesz and the Hungarian Christian Democratic Party, the two parties that ran jointly). Retroactivity refers to the fact that the idea of creating a new political community (or even the adoption of a new constitution) was not part of the political campaign in the elections and needless to say, the principles of this new regime were not up to political deliberation either.

The Declaration (1140/2010), adopted shortly after the new government took office, was to be displayed in all government facilities in Hungary per a government order, which

19 Pap (2017).

20 To create the delusion of popular support, a so-called 'national consultation' was launched. The National Consultation Committee sent questionnaires to all the eight million Hungarian citizens entitled to vote, asking them to answer 13 questions concerning the draft. According to the government (as there were no transparent means to verify this), 12 per cent of voters returned it. See Osvát Osvát (2011).

${ }^{21}$ For a monograph on this subject, see Takács (2015). 
even specified the size, color, fonts and framing details. The President, the Speaker of the Parliament, the Presidents of the Constitutional Court, the Supreme Court and the Central Bank, mayors, ombudspersons, chief prosecutors and judges were requested in the form of a Government Resolution to follow suit. Most state institutions, such as hospitals or universities, also complied. Opposition parties and human rights NGOs considered this duty to display an oath of allegiance an intrusion to the separation of powers and the independence of crucial institutions. The statement issued by the Socialist Party argued that 'This ordinance is Viktor Orbán's letter of resignation from western civilization' and 'the first symbolic step toward building a totalitarian regime that does not tolerate differences of opinion.' Even the far-right party Jobbik (Jobbik Magyarországért Mozgalom Párt Movement for a Better Hungary Party) stated that this action recalls the days when 'one had to put up similar documents next to the pictures of Lenin, Stalin, Rákosi and Kádár'. ${ }^{22}$ Socialist MP's even submitted a satirical bill mocking the Declaration and inter alia, declaring Orbán's birthday a national holiday. ${ }^{23}$ follows:

The political credo of the new regime and the new political community reads as

At the end of the first decade of the 21 st century, after forty-six years of occupation and dictatorship and two turbulent decades of transition Hungary has regained the right and ability of self-determination (...). In the spring of 2010 the Hungarian nation once again summoned its vitality and brought about another revolution in the voting booths. (...) The National Assembly declares that a new social contract was laid down in the April general elections through which the Hungarians decided to create a new system: the National Cooperation System. (...) We, members of the National Assembly declare that we shall elevate the new political and economic system emerging on the basis of the popular democratic will (...) that connect the members of our diverse Hungarian society. Work, home, family, health and order - these will be the pillars of our common future (...). The National Cooperation System is (...) an opportunity for, as well as a requirement of, everybody who lives, works or has an undertaking in Hungary. We firmly believe that we will be able to change Hungary's future through the solidarity represented by the National Cooperation System and build a strong and successful country. This solidarity that releases tremendous energies and gives great hope to every Hungarian (...) and (...) after decades gives a chance to the Hungarians to fulfil[1] their own goals at last. ${ }^{24}$

The term and concept of the SNC was used as a central theme in the government program, submitted to Parliament on 22 May 2010. ${ }^{25}$ The 80 pages long program which contains a subchapter on the 'New Social Contract,' and where the government consistently refers to itself as 'The Government of National Affairs,' is titled 'The Programme of National Cooperation,' and has three chapters: The Declaration of National Cooperation, the (description of) the System of National Cooperation and Issues of National Importance and a joint declaration with the Hungarian Chamber of Commerce and Industry. Let us see some of the highlights of the government program: Hungarians want deep-seated and

22 Hungarian Spectrum, link 13.

23 Krekó, link 17.

24 Official government translation, link 11.

25 Official translation, link 12. 
fundamental change in every area of life. They have authorized more than mere adjustment or change; they have authorized us, through the strength of national cooperation, to establish a new political, economic and social system built on new rules in every area of life. They expect me with all my strength and ability to help the Hungarian community dispose of the old system and create, consolidate and operate a new one. By adopting the Declaration of National Cooperation the new National Assembly has acknowledged the inception of a new social contract in the elections held in April whereby Hungarians decided on the foundation of a new system, the System of National Cooperation. Through this declaration we acknowledge the will of the people and make it the compass of the future.

The government program contains important statements and points of references for constitutional identity. In April 2010 the long period of transition rife with struggles, divisiveness and crises came to an end. The era was brought to an end by the act of the revolution which took place in the polling booths. In spring 2010 for the first time in Hungary since the system change a single political force was granted democratic authority of constituent import. This act imposes historical responsibility on the newly formed parliament. The new parliament is more than Hungary's sixth freely elected parliament. The new Assembly is in fact a constituent national assembly and system-founding parliament. With the two-thirds mandate voters entrusted the new Assembly and the new government using democratic means to carry out revolutionary changes in national issues of the greatest importance. By doing so the country's citizens regained their ability of self-determination and the opportunity by joining forces, instead of pacts and forced compromises, to turn the country in the interest of the common good in a new direction.

The idea that the new government program is actually a new social contract is made explicit: the social contract is the foundation which ensures that the country, in spite of the cyclical nature of the political-economic rotation, develops along a stable path in the direction specified by the people. For lack of a social contract Hungary during the era of transition was controlled by elite agreements and invisible pacts; fruitless debates hampered the country's progress. On account of this the country in recent years was smothered in the battle of private and partial interests; our common national causes were obscured. The current Constitution - as its first sentence reveals - is a temporary, transitional constitution. Its authors intended it as temporary precisely because there was no underlying and valid social contract. The new social contract has now been concluded in the 2010 parliamentary elections.

Legislators have been entrusted over the next four years with the creation of the country's new constitution. The essence of constitutional democracies is that power is exercised by the people. Accordingly, in April 2010 Hungarian voters availed of their right to exercise power and made a firm and clear decision: they gave their blessing, in place of the era of transition and in the spirit of the new social contract, to a new system founded on national cooperation. In constitutional democracies representatives elected by the people exercise power. As during the transition no social contract was born expressing national unity, it was possible in the past eight years for the government to openly turn against the common will and without consequence to abuse the power vested in it. The new social contract was created by national unity revolutionary in its power which expresses the common will of the Hungarian nation. The common will of the nation may not be overridden by any visible or invisible political pact or challenged by any partial interest. This fact compels the country's leaders to do their job, to perform their work in this spirit. With overwhelming force Hungarians ousted the politics which for years went against their will. For this reason, it is the duty of the new National Assembly among its first measures to 
declare that the united will of the people is the main source of power in Hungary. The responsibility of the first government of the new era is to enforce the new social contract, namely to erect the System of National Cooperation. The System of National Cooperation will be the foundation of the country's reconstruction and of the creation of a strong Hungary.

Today Hungary is weak, undergoing times of economic, social and spiritual crisis. However, the social contracts of Western Europe also emerged in situations of crisis. These ambitious agreements also sought solutions for deepening crises of political confidence, as well as for severe economic problems and social ills.

Having identified the agents of the new constitutional identity, the government program sets forth the framework of the modus operandi and administration of the new political community: the new social contract calls for cooperation instead of divisiveness, service of the public good instead of the advocacy of private interests and the strong and effective representation of common national causes. A government for whom the sole benchmark is the nation and the advancement of its members. A government for whom the interests of the individual and the community are not at odds, but rather complement each other.

The System of National Cooperation is built instead of ostracism on unity, instead of political irresponsibility on political responsibility, instead of tolerance of extremes on the rejection and elimination of such, instead of the limitation of citizens' self-determination on the proliferation of such and on the restoration of balance between rights and obligations. The policy of the new government does not have to change the cultural attitudes of Hungarian society - this must stem from other, non-political motives - but it has to change politics and government in order to free up the energies of individual ambition in a way that is beneficial in terms of community building. The public thinking and public sentiment of the era of transition were explicitly/implicitly built on the assumption that individual interests could only be enforced at each other's expense, by weakening each other. In reality, however, individual interests can reinforce each other if this is a conscious part of our efforts.

The System of National Cooperation calls for deep-seated and fundamental change in every important area of government. In the future, instead of private aims and interests, politics must serve common aims and interests. A government and governance is needed which once again turns towards people and their everyday problems and which is based on the representation of our common national causes. A government is needed, therefore, which pays attention to people, listens to them, respects their diversity and understands their concerns. Therefore it represents and enforces those interests which are important to everyone and thus unites, not separates us. Politics are necessary, therefore, which build and develop these common values and strive to make these accessible to everyone. Hungarians are now experiencing that freedom without order breeds chaos and fear. Where order is lacking bars, locks, latches, barriers, cordons and surveillance cameras are soon to follow. Thus work, home, family, health and order are the solid pillars of the System of National Cooperation. In the years to come the Government of National Affairs shall enforce the social contract based on our common values, namely it shall establish the primacy of public good over private interests, the primacy of order over lawlessness, the primacy of safety over unpredictability and governmental chaos and the primacy of economic advancement over debt and vulnerability. The government program, thus, declares a supreme source of political legitimacy, which actually created a new constitutional community, embodied by the government (majority in parliament) and expresses a messianic determination for transformative changes in political and spiritual life: the national unity which came about in 
the elections compels the new government to carry out its electoral program. We are going to fulfil[1] this commitment. Hungarians expressed the will that henceforth common aims and issues of national importance must be served in the System of National Cooperation which unite Hungarians in all their diversity, because they embody those core values which are important to all of us for prosperity and a respectable life: work, home, family, health and order. [Official government translation.]

It is illuminating to look at how the concept and the very term had been used in subsequent government communication. A comprehensive survey of press releases and other entries in the archives of the national news agency, Magyar Távirati Iroda (MTI), which supposedly contains all relevant entries was conducted. The SNC was mentioned for the first time on the night of the elections in Orbán's speech announcing victory. The next time it was mentioned, again by Orbán, was during the first meeting of Fidesz's parliamentary group and a few days later in the opening session of the parliament. He again talked about the SNC at two campaign rallies in May and later in June 2010 when signing an agreement with a leader of Hungarians living in Serbia, where he declared that the System of National Cooperation includes Hungarians living outside Hungary. In parliament, on his $56^{\text {th }}$ (!) day of office, reflecting on the revolution of 1956, the Prime Minister stated that the new political community, which he referred to as the 'national center,' is a community of rationality and his efforts are focused on transforming the two-third parliamentary majority into a political community of a 'central force field,' the system of national cooperation. In a somewhat contradictory fashion, he also said that the reason to govern is to create this 'political center,' and the way to achieve it is the SNC.

In September 2011, on the $100^{\text {th }}$ day of his government in office, Orbán reported to parliament on the development of the four distinct 'national cooperations' of politics, economy, administration and morality - the latter to be elaborated within and by the new constitution. According to this research, the last time he ever mentioned the SNC, was on 23 October 2012 when giving out awards on the national holiday. There was only four other times was the term mentioned by politicians other than Orbán: once by the spokesman for the Prime Minister, the deputy spokesman for Fidesz in political rebuttals, by an undersecretary and an MP in connection with the new law on churches, expressing the importance of including traditional churches in the SNC. After October 2012, this term and concept, so corollary to the new political community that it was ordered to be displayed in state buildings, mentioned by government sources, was not used. After the adoption of the new constitution, the displayed copies of the Declaration of National Cooperation in government offices were mostly replaced by the Preamble of the new constitution, the National Avowal of Faith. ${ }^{26}$

\section{ILLIBERALISM IN THE MAKING: INSTITUTIONAL, LEGAL AND CONSTITUTIONAL DEVELOPMENTS}

Developments in Hungarian political life since 2010 have triggered significant political, academic and media attention. Numerous political decisions, resolutions and reports were adopted by various fora and organs of the Council of Europe, the European Union, the UN

${ }^{26}$ Curiously, while the initial display was ordered by a legal device or measurement, in the form of a government order, the author could not locate a source of law for the replacement, only a communiqué on the Fidesz website. A Nemzeti Hitvallás szövege, link 2. 
and international NGOs like Amnesty International, Freedom House, Transparency International and even judgments from the EU's European Court of Justice and the Council of Europe's European Court of Human Rights. Due to spatial constraints, instead of collecting documents condemning, or even documenting the entire process of how illiberal the illiberal state evolved in Hungary in the past eight years, this article will only provide an overview of the first (and a half) formative and highly intensive year's political and constitutional developments. This is not to suggest or imply that the process ended by 2012 , as Viktor Orbán's regime continues to solidify, proliferate and flourish week by week and this obviously involves both political and legal measures. The new constitution adopted in 2011 was amended for the sixth time in June 2016. This article, however, is limited to outlining developments in 2010-2012, approximately two years, by when architectural sketches of the new regime are finalized and residents have already moved and settled in.

In the following an overview of the process of redesigning the constitutional landscape in Hungary will be provided. It will be shown that illiberalism was present both in the 'how' and 'what' is being done - in the style, format and procedure of legislation as its substance. The adoption of the new constitution is an important part of the process and can even be seen as a landmark but in many cases it only cemented earlier achievements and innovations of a legislative juggernaut.

Kornai $^{27}$ points out that 859 laws were passed between 2010 and 2014, nearly twice as many (399 more) as during Orbán's first government between 1998 and 2002 and almost 150 per cent (274 laws) more than in the 2006-2010 cycle. Orbán's supermajority basically eliminated Parliament from the political process as an autonomous instrument for democratic deliberation and a tool to control government. Reforms, enacted by parliamentary legislation, have been extremely swift - in its first 20 months in office, the government pushed through 365 laws. This included 49 cardinal laws, which require a two-thirds majority but there was no adequate consultation with opposition parties and civil society. In this time, twelve amendments were made to the (old) constitution that together changed more than 50 individual constitutional provisions. ${ }^{28}$

Most legislation was introduced to parliament as individual members' bills. Since the government is formally not involved in these Bills, these do nt require a detailed debate, consultation, impact assessment and traditional venues for negotiation with the civil sector. Scheppele ${ }^{29}$ highlights that ten of the twelve constitutional amendments and even the new constitution were private member's bills, which, instead of being a tool for the parliamentary minority, became an instrument to entrench the government's super-majority. Kornai ${ }^{30}$ lists 13 laws that were passed in less than a day. To be safe and legally solid, the Fidesz majorityled parliament passed a change to the rules of parliamentary procedure, which requires only a two-thirds majority (as opposed to the formerly required four-fifth) to approve an extradited procedure for a bill to go from first proposal to final vote without debate and consultation. Even for the Bills that were submitted by the Government, deadlines set by Ministries for public debate and commenting were very tight, sometimes only a few days. For example, the Bill on petty offenses (2012), ${ }^{31}$ which had a deadline of six working day,

27 Kornai, link 16.

28 Halmai and Scheppele (2012).

29 Scheppele, link 21.

30 Kornai, link 16.

31 Act II of 2012 on petty offences, on petty offence procedure and the petty offence registry system. 
was sent out for commenting on the 95 page long text, while in the case of the 29- and 97-page-long draft Bills on the legal status of prosecutors $(2011)^{32}$ and the Prosecution Service (2011), ${ }^{33}$ the respective Ministry provided not more than one day for comments by professional chambers, civil society, etc.

Laws have often been amended substantially after the parliamentary debate through the use of a special measure aimed at eliminating technical and incoherent provisions. Several pieces of legislation were specifically tailored to accommodate particular acts of favoritism, such as lowering age requirements for ambassadors to enable the appointment of a government loyalist or changing incompatibility regulations to enable former military service members to run for elected office. Kornai ${ }^{34}$ lists eight documented cases where laws were amended in order to make certain candidates eligible.

The same strategy was used to remove non-government appointees from office. For example, shortly before the European Parliament elections, the tenure of the members of the National Election Committee, the independent supervisory body of the legality of the elections, was terminated under the auspices of the reorganization of the institution. A similar strategy led to the dismissal of the National Radio and Television Body, the Data Protection Commissioner (ombudsman) and even the President of the Supreme Court. Government clientelism cementing loyalists into power even for the future when the government may lose its two third majority was achieved by passing legislation that infinitely extends the mandates for public offices if parliament fails to elect the successor, often by a supermajority. Such offices include the prosecutor general, constitutional court judges.

The political-legislative strategy of 'over-constitutionialisation', that is amending the Constitution/Fundamental Law in order to legitimize unconstitutional legislation, has also been applied on numerous occasions. In the first few months, several acts of parliament were struck down before the Constitutional Court was castrated and deprived of many of its competences. In order to remedy these obstacles to the supermajority's legislative efforts, the constitution would promptly be amended respectively - the Constitutional Court may not review the constitutionality of constitutional amendments.

Parliament also passed a bill of attainder legislation, directly engaging in modifying court decisions. Shortly after the elections, a parliamentary subcommittee was established to investigate responsibility for occasional use of force against anti-government demonstrators and rioters before the elections, when Fidesz was in opposition. The subcommittee subpoenaed judges and called for the review of judgments. This practice was held to be a violation of judicial independence by the President of the Supreme Court and the National Council of Justice. On 7 March 2011, Parliament adopted the Nullification Act, annulling and condemning court decisions.

Also, the 2012 Act on the National Assembly vested the Speaker of the Parliament with extensive discretionary powers to limit MPs' free expression, including the authority to fine MPs even for displaying the EU-flag, which was removed from the Parliament building. Journalists' freedom was also severely limited in terms of moving about in the premises or recording and broadcasting sessions. Monopolies were given to reporters and

32 Act CLXIV of 2011 on the legal status of the Chief Public Prosecutor, prosecutors and other prosecution service employees and on prosecutors' career path.

33 Act CLXIII of 2011 on the Prosecution Service.

34 Kornai, link 16. 
photographers of the National News Agency and some reporters (from index.hu) were banned entry for months for having 'violated the dignity of the Parliament'.

An important institutional action in building the Hungarian illiberal democracy was aimed at dismantling the Constitutional Court. Severe measures to weaken the competences of the Constitutional Court have been introduced, such as the elimination of actio popularis procedures for ex post review, the abolition of powers to review all budget-related legislation ${ }^{35}$ and repealing all court decisions made before 1 January 2012 (when the new Constitution entered into force) so that precedents of the Court cannot be invoked in new cases based on the new Constitution. Additionally, the number of justices has been raised from 11 to 15 , allowing the government to nominate and elect seven judges (out of a body of 15) within a few months, the procedural requirement to try to reach a consensus within parliament regarding their election was eliminated. By now, all of the judges are government loyalists, two former members of Orbán's first government, several having been appointed directly from their positions as (majority) members of parliament. The new laws allow 'infinite membership' for judges should a new member not be elected by a two-thirds majority by the time the term of office of the judge ends. The new provisions also provide that only the Government, one-fourth of MPs and the Commissioner of Human Rights are entitled to request ex post review of any piece of legislation. In post-2010 constellation it is almost impossible that one-fourth of the opposition MPs would submit such a motion together as it would require an unlikely coalition of the far-right and the Socialists. The possibility of turning to the Constitutional Court became even more difficult as legal representation turned mandatory and legal aid is not available for this purpose. At the same time a procedural fine ranging from 20,000 to 500,000 HUF (70 to 1,700 EURs) may be imposed on petitioners initiating procedures in an 'abusive' way, the sum of the fine is due to the Constitutional Court. The uncertainty of the word 'abusive' might deter many from turning to the Constitutional Court. ${ }^{36}$

In an attempt to weaken the independence of the judiciary, the six-year-long mandate of the former President of the Supreme Court was prematurely ended after two years and the mandatory retirement age for all judges was reduced from 70 to 62 years of age a move that practically removed all court-presidents (chief judges) with replacements to be chosen by the head of the newly created administrative unit. A new powerful administrative organ for the judiciary titled the National Judicial Office was created with powers to appoint judges. The body is presided by one of the new constitution's drafters who is also the wife of a Fidesz member of the European Parliament and a longtime friend of the Prime Minister. Her mandate, similarly to the Prosecutor General, a former Fidesz MP-candidate, is also automatically prolonged if no new President is elected by the two-thirds of Parliament. Halmai argues that 'According to the new act on the judiciary, any judge in the ordinary courts can be elevated or demoted by this single state official, who has the sole power to appoint judges and no other judicial bodies have a decisive role in the process. ${ }^{37}$

35 The right to review financial laws is restricted to review from the perspective of rights (the right to life and human dignity, protection of personal data, freedom of thought, conscience and religion, or the right to Hungarian citizenship), that they typically cannot breach. The restriction remains in effect for as long as state debt exceeds half of what is referred to in the Hungarian text as the 'entire domestic product', the content of which is uncertain. See The Fundamental Law of Hungary (25 April 2011), The State, Public Finances Article 37 (4).

36 Halmai, link 8.

37 Halmai, link 8 . 
Another innovation that raises questions about the independence of the judicial process is that despite traditional rules for designating judicial fora, the President of the new National Judicial Office as well as the Prosecutor General have been authorized to appoint courts for hearing individual criminal proceedings. The Prosecutor General, whose mandate was extended from 6 to 9 years, is neither responsible to the Government nor to the Parliament- they only have the duty to report to the Parliament annually and MPs only have the right to pose questions to them; the right to pose interpellations was abolished. ${ }^{38}$

A single Office of the Commissioner for Fundamental Rights was created which replaced four formerly independent parliamentary ombuds-institutions. The portfolio of the former Ombudsperson for Data Protection and Freedom of Information was transformed into a quasi-governmental office. Since the institutions of the Parliamentary Commissioner for the Rights of National and Ethnic Minorities and the Parliamentary Commissioner for Future Generations, the ombudsperson responsible for environmental issues, were abolished, the mandate of the respective Commissioners was also terminated before the end of their term of office. ${ }^{39}$ For the new ombuds office, the (Parliamentary) Commissioner for Fundamental Rights parliament elected a civil law professor and former Fidesz-government commissioner who had no any constitutional or human rights track record.

The Fundamental Law also creates a National Budget Council, an unelected body with limited democratic legitimacy, with members chosen by the government, tenured for up to 12 years, who can only be replaced if two-thirds of the parliament can agree on the successors. The new body can practically veto the budget. According to the new constitution, if parliament fails to pass a budget by March 31 of each year, the Head of State, elected by a simple majority, with a mandate exceeding that of the parliament, can dissolve the parliament and call new elections. ${ }^{40}$ Thus, if Fidesz is outvoted in the next elections, severe constraints burden any future government and, for example, Scheppele argues that if Fidesz loyalists can veto the budget by making it miss the deadline, the President (also named by Fidesz) will call new elections. This can be repeated until an acceptable government is voted back into power. ${ }^{41}$

The government also introduced a substantial reform concerning self-governments (Act CLXXXIX of 2011 on local governments). Besides restructuring local elections, most administrative competences (including healthcare and secondary education) have been

38 The Council of Europe's European Commission for Democracy through Law (Venice Commission) issued a special report on the case, link 26. On 17 January 2012, the EC launched an accelerated infringement proceeding against Hungary regarding the independence of the judiciary. In 2016 the Grand Chamber of the European Court of Human Rights held that Hungary had been in violation of Article $6 \S 1$ (right of access to a court) and of Article 10 (freedom of expression). See Baka v. Hungary, App. No. 20261/12 (June 23, 2016), link 4.

39 In 2014 the Grand Chamber of the EU's European Court of Justice held in the infringement procedure inititated by the European Commission that, by prematurely bringing to an end the term served by the supervisory authority for the protection of personal data, Hungary has failed to fulfill its obligations under Directive 95/46/EC of the European Parliament and of the Council of 24 October 1995 on the protection of individuals with regard to the processing of personal data and on the free movement of such data. Case C-288/12, European Commission v Hungary (April 8, 2014), link 5.

40 The Fundamental Law of Hungary (25 April 2011), The State, The National Assembly Article $3(3) b)$.

${ }^{41}$ Scheppele, link 22. 
removed from elected local municipalities to either central regional administration or to newly established administrative entities.

Rewriting of the regulations of the press and electronic media was a highly significant stage of the transformation of the Hungarian constitutional order. Through two new laws, the government did not simply establish such a wide-ranging government control of the print and electronic media that is unprecedented in constitutional democracies but also abolished the safeguards against unilateral political influence. Without these safeguards, the governing majority had the opportunity to create an entirely politically homogeneous body with all its members nominated by the governing party, to oversee compliance with the rules. As a result of these measures (Act CIV of 2010 on the freedom of the press and the fundamental rules of media content; Act CLXXV of 2010 on media services and mass media), the freedom of the press, which has a key role in holding those exercising public authority accountable, has been curtailed to an extraordinary degree.

Newly adopted rules also allowed for the dismissal of civil servants without justification. As a result, thousands of civil servants were fired from public administration positions. ${ }^{42}$ The law was held to be unconstitutional by the Constitutional Court and was squashed pro futuro. Dismissals nevertheless continued.

According to Freedom House ${ }^{43}$, by 2014 all major independent institutions were headed by partisan or personal loyalists who (in Scheppele's words) 'will be able to conduct public investigations, intimidate the media, press criminal charges and continue to pack the courts long after the government's current term is over ${ }^{\text {'44 }}$. Former members of the Fidesz parliamentary group have been elected as President of Republic, the Head of the State Audit Office and one member of the Constitutional Court, while the president of the Central Bank and another judge of the Constitutional Court was a member of the previous Fideszgovernment.

Besides the government taking political control over the Election Commission, electoral reforms introduced a remarkable form of gerrymandering that disproportionately favors the governing parties. In April 2010, both the local election and the parliamentary election law have been rewritten (Act CCXXXVIII of 2013 on referenda, Act XXXVI of 2013 on electoral procedures, Act CCIII of 2011 on parliamentary election, Act L of 2010 on local elections). The overhaul of both laws includes more stringent ballot access requirements and a greater weight for the majoritarian element of the mixed election system. The parliamentary election law also involves a redrawing of single-member district (hereinafter SMD) boundaries with a view towards giving the ruling parties more seats. The new law has roughly halved the number of MPs in Parliament (386 to 199) and has correspondingly also reduced the number of SMDs from 176 to 106 . In parliamentary elections, the proportion of seats distributed in the majoritarian SMDs rises from 46 per cent of all seats to 53 per cent of all seats. Coupled with the advantages from gerrymandering, this could give the ruling parties a parliamentary majority even if they fall far shy of a popular majority. ${ }^{45}$

In local elections, previously 60 per cent of local council members were elected in SMDs and now 70 per cent are, while the proportion of counselors elected on proportional party lists shrank accordingly from 40 per cent to 30 per cent. In effect, party preferences as

42 HCLU, link 10.

43 Freedom House, link 6.

44 Scheppele, link 22.

45 Karacsonygergely.blog.hu, link 15. 
expressed in votes submitted for party lists will have considerably less impact on the distribution of seats in parliament and local councils.

By amending Act LV. 1993 on Hungarian citizenship (Act XLIV of 2010 on Hungarian citizenship), Parliament has allowed the possibility of persons who were previously citizens of Hungary, or whose ancestors were citizens of Hungary, or who are of Hungarian descent but are now foreign citizens, to receive Hungarian citizenship. The new electoral law abolished residency requirements for eligibility to vote, but instituted a construction, where non-residents' votes are worth less than half than those of residents as since they do not have SMDs and cannot vote for SMD candidates, their votes are counted only in the national list. Estimates of the size of the ethnic Hungarian communities across the border vary, ranging between $2.5-3$ million. ${ }^{46}$ It needs to be added that voters are also discriminated against on the basis of residence - Hungarian residents who work or study abroad cannot vote by mail but need to travel to a Hungarian embassy or consulate, whereas non-resident citizens can cast their votes from home. ${ }^{47}$ Central European University professor and citizenship scholar Szabolcs Pogonyi ${ }^{48}$ showed that these non-resident votes actually played a crucial role in the final mandate allocation at the 2014 April parliamentary elections: 600,000 non-resident Hungarians had acquired citizenship, 193,793 registered to vote, but as a result of the overcomplicated voting procedure, only 128,429 valid mail votes were cast, with Fidesz receiving the overwhelming 95.4 percent of these votes. Fidesz won 133 seats in parliament - exactly the number necessary for the two-third majority. Votes from the non-resident constituency secured one crucial seat for Fidesz. ${ }^{49}$

The new constitution also changed the rules on the validity of a national referendum at least half of all eligible voters must cast a valid vote to have a valid referendum result, while the previous Constitution (Act XX of 1949, The Constitution of the Republic of Hungary) only required that a quarter of all eligible voters cast a vote on one side of the issue. Most referenda held since the regime transition would have failed to meet the new criterion, including the referenda on NATO and EU membership. ${ }^{50}$

The Fundamental Law also expanded the list of legislative issues that require a qualified majority, covering a wide range of issues beyond political institutions and fundamental rights. A two-thirds majority is required for regulations concerning family law, the tax and pension systems, cultural, religious, socio-economic and financial policies which normally fall within the sphere of competence of the government or are covered by the regular decision-making powers of the legislature.

It needs to be emphasized that the Orbán-regime's illiberalism is most often portrayed as the democratic backlash that surfaces first and foremost in the dismantling of institutional rule of law guarantees, the weakening of checks and balances but, apart from the recent but

46 Kiss (2004), Gyurgyik, (2005); Transindex.ro, link 27.

47 Both the European Court of Human Rights (Vámos and others v. Hungary, App. No. 19398/11 (Nov. 17, 2016), and the Hungarian Constitutional Court \{Hungarian Constitutional Court [Alkotmánybíróság], April 19, 2016, Decision No. 3086/2016. (IV. 26.) rejected appeals in this regard, arguing that the equality of votes is not violated, since non-residents form a different group, as they only have one vote. Ironically, the same rules apply for national referenda, where all voters have only one vote, answering to the same questions.

48 Pogonyi (2015).

${ }^{49}$ In 201426.6 per cent of eligible voters and 53.1 per cent of all voters choose Fidesz, which gained 66.8 per cent of parliamentary mandates. Kornai, link 16 .

50 Szigetvári, Tordai and Vető, link 25. 
notable developments of attempting to close down the privately funded Central European University and an assault on $\mathrm{NGOs}^{51}$ the systematic abuse of fundamental rights and individual freedoms is not part of the package (as yet). However, Hungarian illiberalism also takes the form of ideological commitments and biases in legal and constitutional documents. The new constitution fails to recognize individual autonomy as a constitutional principle and contains a number of ideological commitments and constitutionally enshrined value preferences which enables future legislation that may restrict autonomy and freedom in all sorts of ways. For example, Article L of the Fundamental Law holds that: '(1) Hungary shall protect the institution of marriage as the union of a man and a woman (...) and the family as the basis of the survival of the nation.' It also states that '[f]amily ties shall be based on marriage and/or the relationship between parents and children.' This formulation recognizes parent-child relations that have emerged outside of marriages but not the civil law partnership of the parents. This is a clear expression of a moral preference that denies the equal recognition of the plurality (freedom) of forms of life, the neutrality of (and tolerance by) the state and respect for personal autonomy. ${ }^{52}$ Another example is Article II of the Fundamental Law which holds that 'Every human being shall have the right to life and human dignity; the life of the fetus shall be protected from the moment of conception.' Hence, the new constitution authorizes legislation restricting abortion or even prohibiting in-vitro fertilization but no such initiatives have been floored so far.

\section{ILLIBERALISM AND THE SYSTEM OF NATIONAL COOPERATION}

Having outlined the morphology, the next step is to explore the ontology of Orbán's selfproclaimed illiberalism and the identification of his regime as an illiberal democracy, or more precisely an 'illiberal state'. No normative legal document, formal political manifesto, or official government communication ever provided a coherent description of the nature, design, or constitutional philosophy of the Hungarian illiberal democracy model. It is therefore the task and challenge of academic analyses to decipher its normative and analytic content. It will argued that Hungarian illiberal democracy manifests itself in the SNC a vaguely defined, yet even normatively presented political construct in which majority rule may operate unbounded by the rule of law, separation of powers and other constraints of liberal democracies. The SNC, which was never actually defined or explained in a normative document or even in a political manifesto, is arguably both the conceptualization and a metaphor of the political community. Although it is not a formalized set of political institutions, it is the conceptualization of the illiberal democratic decision-making process, which makes traditional constitutionalism obsolete.

It needs to be added that illiberalism was not part of the first marketing package of the SNC. On the contrary, the aforementioned 2010 government program of 'National Cooperation' contained several commitments to liberal democracy and even a quote from Abraham Lincoln:

The Government of National Affairs intends to pursue a policy that ensures everyone the greatest possible freedom [...] Overall, given our aims, we can avow the words of Abraham Lincoln as applicable to us: 'It is rather for us to [ensure] [...] that this nation,

51 BBC.com, link 14., Amnesty.org, link 3.

52 Halmai and Scheppele, link 7. 
under God, shall have a new birth of freedom - and that government of the people, by the people, for the people, shall not perish from the earth'.53

Part 5.1 contains important references to Fidesz's self-proclaimed identity. It starts by stating that 'We will remain loyal to the ideas of democracy and the rule of law,' as 'Fidesz was formed in 1988 (...) so that Hungarians can live in real democracy enjoying the same freedom and wealth as Western-European states.' It continues by holding that 'Fidesz Hungarian Civic Union has for 20 years consistently represented politics which rests on unconditional respect for solidarity, freedom, civil rights and human dignity, as well as legal certainty. ${ }^{54}$ The reader is ensured of the party's commitment to freedom and the rule of law:

True wealth is inconceivable without freedom. The most important guarantee of freedom is, in turn, law and order and therefore the principal task of the current Government is to defend the property of its citizens, legal certainty and legality. At the core of it is the imperative that the State itself respects the law. Compliance with the norm is not only an obligation binding on the citizen, but is a fundamental requirement the possessors of power must fulfil[1] themselves. Within the frame of the rule of law it is unacceptable for the Government, in possession of parliamentary majority, to pass unconstitutional laws and thus expose its citizens to uncertainty, also jeopardi[z]ing the principle of legal certainty. ${ }^{55}$

\section{ILLIBERAL DEMOCRACY AS CONSTITUTIONAL IDENTITY}

Illiberalism as a chosen feature of the new regime was introduced by Orbán, at a speech delivered at the Summer Open University of Bálványos in July 2014. ${ }^{56}$ This immediately went viral and was reported widely in international media. Here Orbán identified his regime as illiberal in the following manner:

(...) while breaking with the dogmas and ideologies that have been adopted by the West and keeping ourselves independent from them, we are trying to find the form of community organi[z]ation, the new Hungarian state, which is capable of making our community competitive in the great global race for decades to come. (...) [A] democracy does not necessarily have to be liberal. Just because a state is not liberal, it can still be a democracy. (...) [U]ntil now we have known three forms of state organi[z]ation: the nation state, the liberal state and the welfare state. And the question is, what's next? The Hungarian answer to this question is that the era of the work-based state is approaching. We want to organi[z]e a work-based society that, as I have just mentioned, undertakes the odium of stating that it is not liberal in character. (...) [W] e must break with liberal principles and methods of social organi[z]ation and in general with the liberal understanding of society. (...) [A]nd forge a new method of Hungarian state organi[z]ation (...), following [in the sense of bypassing (..), ALP]

53 Office of the National Assembly, link 12.

54 Office of the National Assembly, link 12.

55 Office of the National Assembly, link 12.

56 Kormany.hu, link 1. 
the liberal state and the era of liberal democracy (...) we suggest and are attempting to construct Hungarian state life around this idea, that (liberalism) should not be the principle on which society is built. (...) the Hungarian nation is not simply a group of individuals but a community that must be organi[z]ed, reinforced and in fact constructed. And (...) the new state that we are constructing in Hungary is an illiberal state, a non-liberal state. (...) [W]we want to organi[z]e our national state to replace the liberal state, construct a new state built on illiberal and national foundations within the European Union. (...) [T] he Government has come to a decision according to which within this new state concept, this illiberal state concept, the reorgani[z]ation of the Hungarian state is underway, in contrast to the liberal state organi[z]ation logic of the previous twenty years. ${ }^{57}$

Csillag and Szelényi ${ }^{58}$ argue that 'liberalism' for Orbán means the excessive emphasis of individual interest over the 'national' interest. Orbán envisions that in the next 15-20 years Hungary should be dominated by a single, massive right-wing political party that would rule the whole political field without 'unnecessary' debates. ${ }^{59}$ Although the populist rhetoric (of the SNC) aims at targeting and attracting both moderate and far-right voters, the SNC is not inherently and intrinsically racist, misogynist, anti-Semitic, or homophobic. It does, however, neglect and deny the discursive recognition and questions the importance, relevance and legitimacy of liberal values and fails to adopt an individual freedom and human rights oriented approach that would, for example endorse Roma inclusion, feminism and multiculturalism, post-nationalism, individualism, or a particular vision of modernism - ideals and commitments Hungarian liberal public intellectuals would advocate. ${ }^{60}$ In other words, the discourse is not inherently anti-liberal, only 'a-liberal'.

It needs to be noted here that Orbán, the omnipotent charismatic leader and his party Fidesz before its sharp turn to the right in 1993, which a former mentor and political ally Miklós Haraszti calls a purely political maneuver, ${ }^{61}$ was

the ultimate anarcho-liberal, a pupil and an embodiment of the Democratic Opposition's underground culture. (...) He has led himself and his Fidesz party from radical antiauthoritarians to radical Christian-Conservatives. He took pride in 1990 in making Fidesz a member of the Liberal International one step earlier than SZDSZ (the Alliance of Free Democrats), the leading opposition party in 1990-94 and Fidesz's political and ideological role model before and during the roundtable talks and the transition. Michael Shafir calls this the crowning of the party's 'transfiguration,' when it left

57 Speaking in interview with Bloomberg, Orbán said the following: "Hungarians welcomed illiberal democracy. The fact that in English it means something else is not my problem. In the Hungarian context, the word liberal has become negative. Liberal democracy has no or very little support in Hungary. What I want to say is that it's not true that a democracy can only be liberal'. Simon, link 24.

58 Szelényi and Csillag (2015) 23.

59 Rácz, link 20.

${ }^{60}$ This is not to argue that liberalism is necessarily multicultural, or that any form of collectivistic constitutionalism would be inherently liberal, only that these would be the most characteristic and typical commitments by Hungarian liberal public intellectuals (who, in the absence of a visible liberal party, can be identified as relevant 'liberal' voices.)

61 Haraszti, link 9. 
the Liberal International and joined the conservative European People's Party in $2010 .{ }^{62}$

Thus, allegiance to illiberalism is also a quasi-Freudian reiteration of Orbán's conservative turn in 1993 and the formal and overt rejection of his party's initial liberal commitments to values and principles such as human rights, inclusive intimate citizenship, cosmopolitanism, modernism, political correctness and multiculturalism - commitments endorsed by liberal politicians and intellectuals in Hungary. Illiberal democracy as per Orbán is a manifesto against the now mostly imagined, but habitually demonized archenemy, a once envied powerful and popular father-party advocating the above liberal values and commitment. Returning to the seminal Orbán-speech:

the Hungarian nation is not simply a group of individuals but a community that must be organi[z]ed, reinforced and in fact constructed. And ... the new state that we are constructing in Hungary is an illiberal state, a non-liberal state. It does not reject the fundamental principles of liberalism such as freedom and I could list a few more, but it does not make this ideology the central element of state organi[z]ation, but instead includes a different, special, national approach.

He points out that 'this cannot be entered into law, we are talking about an intellectual starting point now.' Thus, illiberalism in Hungary goes beyond political and legal action. It is a form of ideology and a discursive construct. Self-identified 'unorthodox' legal and political institutions are instrumental for the establishment, solidification and cementing of the Orbán-regime but they are only byproducts. The real product is the (conceptual framework of the) newly established political community. Illiberal democracy and the SNC serve as tools for constitutional identity and an ideological framework for institutionalizing the well-documented process of anti-democratic backlash in Hungary.

Therefore, despite all illiberal and anti-democratic legal and constitutional developments, the specificity of Hungarian illiberal democracy (or illiberal state) can better be characterized by a not institution-focused analysis. The core and essence of 'Hungarian illiberal democracy' is neither a construct of constitutional philosophy nor is it a principle for constitutional design. It goes beyond the enumeration of the evisceration of classic democratic institutions and it is also not characteristically illiberal within the interpretative framework of political theory. It would equally not qualify as a sui generis un-republican, ${ }^{63}$ un-participatory, ${ }^{64}$ un-agonistic, ${ }^{65}$ or un-deliberative model ${ }^{66}$ Despite the political mantra used by Orbán's party of the legitimating force of a parliamentary supermajority being based on a single event of popular vote, the Hungarian model of illiberal democracy cannot be equated with the unfettered freedom of a parliamentary majority to do as it pleases. Rather, it is a tool to channel, define and dominate general political discourse and to provide a discursive framework for political identification and ideologically biased yet divergent and ad hoc legislation.

It is argued that 'illiberal democracy' and 'illiberalism' in Hungary are actually forms of constitutional identity guiding the discursive framework of this new political community.

62 Shafir, link 23.

${ }^{63}$ Niederberger and Schink (2013), Pettit (2013).

64 Garcia (2015).

65 Wenman (2013).

${ }^{66}$ Gutmann - Thompson (2002). 
Illiberalism is thus the culmination of government discourse along with the discursive framework of the new political community, which in turn reframes politics in terms of nationhood. It is the form and means to construe and express the new and novel (constitutional) identity, which emphasizes cultural particularism and values such as fidelity, faith and charity as opposed to universal values of equality, human rights and social inclusion. This creates official historical narratives but disregards individual autonomy and projects a paternalistic conception of society in which value preferences are not centered on liberty and autonomy. Orbán's illiberal democracy instrumentalizes a special form of nationalism that is built on the uniqueness of the Hungarian 'people,' where illiberalism is a form of ethno-symbolism. According to the concept of ethno-symbolism, nations are based on ethnic groups, where cultural cohesion is built on myths and symbols. ${ }^{67}$ Here, the myth of election of the new political community via the $\mathrm{SNC}$ is constituted through independence from modernist universalist values, which only brought failure and frustration. This framework for constitutional identity politics centers on the rejection of the liberal political ideology that places individual freedom front and center.

The metamophosis of this Hungarian model for illiberal democracy manifests itself normatively through value preferences expressed in the new constitution, the Fundamental Law, as well as in a quasi-normative political declaration that serves as a manifesto for not only Orbán's new political regime, but also the new political community he and his regime envisages. It is important to highlight that, contrary to what it claims to be, the SNC is not an actual institutionalized modus operandi for the Hungarian illiberal democracy, nor is it a form of political institutional design. It is rather the manifesto of illiberal democracy - the political and quasi-normative declaration of the Orbán-regime's discursive framework.

To summarise the quintessential feature of the Hungarian illiberal democracy is that it is the discursive framework through which the Orbán-government has constructed a new national and constitutional identity. It is a form of a constitutional commoditization aimed at selling a political regime where a significant emphasis is put on authenticity and difference. Thus, illiberalism is not so much a constitutional term describing and legitimizing an overall backlash in democratic control mechanisms and the protection of human rights as it is a discursive framework constructed to describe and market (see Comaroff and Comaroff for the concept $)^{68}$ the new imagined community of the SNC-Hungarian nation and to narrate its shared common belonging. ${ }^{69}$ To paraphrase Thierry Balzacq's securitization theory, it may be argued that the Hungarian illiberalisation process is a perlocutionary constitutional speech act (for the original theory, see Austin) ${ }^{70}$, in which the consequential effects or sequels aim to evoke the feelings, beliefs, thoughts or actions of the target audience. ${ }^{71}$ 'Illiberalism' is a mobilizing tactic utilized to question the validity and

${ }^{67}$ Anthony D. Smith explains how myths are highly significant factors in nation building. Smith (1996), Smith, (1999), Smith (2009). Also consider John Armstrong arguing that 'A most significant effect of the myth recital is to arouse an intense awareness among the group members of their "common fate". Armstrong (1982).

${ }^{68}$ Comaroff and Comaroff (2009).

${ }^{69}$ For scholarly assessments on the role of discursive action in the process of identity formation. Cohen (1985), Fox and Miller-Idriss (2008), Wodak (2009).

70 Austin (1962).

71 Balzacq argues that three different aspects should be considered when analyzing perlocutionary speech acts: (i) the centrality of the audience; (ii) the co-dependency of agency and context; (iii) the dispositive and structuring force of practices. Balzacq (2010). 
sustainability of post WWII (liberal) consensus on human rights centered on political language, disenchantment, certain sacred democratic institutions and neoliberal policies. The term, which is not a coherent concept, can be operationalized by neoconservative movements as an anti-modernist and fundamentalist $\mathrm{t}^{72}$ answer to the neoliberal consensus, similarly, for example, to the ways in which '(anti) gender ideology' is used. Kováts et. al. have argued that 'gender' has been identified as the common ground, a label amidst diverse political cultures, different party structures and a variety of mobilizing tactics, compressing different fears and values and used against diverse causes. ${ }^{73}$ Orbán's illiberalism is also very similar to how Hobsbawm ${ }^{74}$ sees nationalism in the $21^{\text {st }}$ century - as a substitute, a placebo for disorientation and a surrogate for integration in a disintegrating society; when society fails, the nation appears as an ultimate guarantee (and in post-communist societies, also as a device to distinguish between the innocent and the guilty). In the Hungarian case, the strategy worked. As Petö and Vasali ${ }^{75}$ point out, the government successfully built a state-funded (pseudo) NGO sector and this, alongside racist and nationalist movements, ${ }^{76}$ convincingly offered anti-modernism and anti-cosmopolitanism/Europeanism ${ }^{77}$ as a viable alternative to neo-liberal democracy and the market economy.

Similarly to the grand vision of the national system of cooperation, the concept of (announcing and defining) Hungary as an illiberal democracy, in contrast to its corollary status, does not appear to be something government communication would utilize for the long term. In fact, it creates the impression of a mere short-term marketing slogan, a tool to control public discussion and media attention. According to the aforementioned media analysis I carried out, as I already mentioned above, using the database of the national news agency, which is mandated to document all relevant government and public communication, the term and the concept was used only seven times. Five times by Orbán: following the seminal speech, once in a debate in the Hungarian, once in the European Parliament and once during a press conference following a meeting with German Chancellor Angela Merkel, who specifically mentioned her concerns in regards of this statement, as well as in an interview in the German economic weekly, Wirtschaftswoche. The two other substantive references were made by Orbán's spokesperson and by one of his cabinet members. ${ }^{78}$

\section{CONCLUSIONS}

To sum up the findings of the thought experiment, which built on the presumption that there is a substantive theoretical construction behind legislative and political developments and it can and is worthy of being deciphered, this article made the following arguments.

First, the Orbán-government's self-proclaimed revolutionary regime claims to have reconstituted and re-conceptualized the relationship between the state and its citizens, both in institutional and normative terms. For example, the Republic of Hungary was renamed Hungary.

72 Vidra, Horváth and Fox (2012).

73 Kováts, Põim and Tánczos (2015), Kováts and Põim (2015).

74 Hobsbawm (1992).

75 Petö and Vasali, link 19.

${ }^{76}$ For more, see Feischmidt and Hervik (2015), Vidra and Fox (2014), Wodak, KhosraviNik and Mral (2013).

77 Melegh (2006).

78 Kovács - Horváth - Vidra (2011). 
Second, the new regime in several fields of life made a significant departure from the constitutional standards generally held in liberal democracies. However, neither its creators argued convincingly, nor could an academic analysis support the claim that this would indeed constitute a new, coherent, sui generis illiberal democracy model from the constitutional legal or the political theoretical point of view.

Third, this self-identified illiberal regime, however, sets forth a political discourse and a discursive framework that also materializes in the form of legal, constitutional documents, which reject ideological and policy commitments towards human rights and an autonomy centered, and in this sense liberal, concept of personhood.

\section{LITERATURE}

Act CLXIII of 2011 on the Prosecution Service.

Act CLXIV of 2011 on the legal status of the Chief Public Prosecutor, prosecutors and other prosecution service employees and on prosecutors' career path.

Act II of 2012 on petty offences, on petty offence procedure and the petty offence registry system.

Anderson, Perry, 'Russia's Managed Democracy' (2007) 29 London Review of Books 3-12.

Armstrong, John, Nations Before Nationalism (The University of North Carolina Press 1982).

Austin, John Langshaw, How to Do Things with Words (Harvard University Press 1962).

Balzacq, Thierry, Securitization Theory: How Security Problems Emerge and Dissolve (Routledge 1st ed. 2010).

Bozóki, András and Ádám, Zoltán, 'State and Faith: Right-wing Populism and Nationalized Religion in Hungary' (2016) 2 East European Journal of Society and Politics 98-122.

Bozóki, András, 'Occupy the State: The Orbán Regime in Hungary' (2011) 19 Journal of Contemporary Central and Eastern Europe 649-63.

Canovan, Margaret, 'Trust the People! Populism and the Two Faces of Democracy' (1999) 47 Political Studies 2-16.

Cohen, Anthony Paul, Symbolic Construction of Community (Routledge 1985).

Collier, David and Levitsky, Steven, 'Democracy with Adjectives: Conceptual Innovation in Comparative Research' (1997) 49 World Politics 430-51.

Comaroff, John and Comaroff, Jean, Ethnicity (Chicago Studies in Practices of Meaning 2009).

Feischmidt, Margit and Hervik, Peter, 'Mainstreaming the Extreme: Intersecting Challenges from the Far Right in Europe' (2015) 1 Intersections East European Journal of Society and Politics 3-17.

Finchelstein, Federico, 'Returning Populism to History' (2014) 21 Constellations 467-82.

Fox, Jon and Miller-Idriss, Cynthia, 'Everyday Nationhood' (2008) 8 Ethnicities 536-76.

Garcia, Luis Bouza, Participatory Democracy and Civil Society in the EU: Agenda-Setting and Institutionalisation (Palgrave MacMillan 2015).

Gutmann, Amy and Thompson, Dennis, Why Deliberative Democracy? (Princeton University Press 2002).

Gyurgyik, László, 'Magyar kisebbségek a kutatások tükrében: A határon túli magyarok számának alakulása az 1990-es években' (Hungarian Minorities in Researches: Hungarians in the Neighbouring Countries and Their Numbers in the 1990s) (2005) 2 Magyar Tudomány 132-44.

Halmai, Gábor and Scheppele, Kim Lane (eds.) Opinion on Hungary's New Constitutional Order: Amicus Brief for the Venice Commission on the Transitional Provisions of the Fundamental Law and the Key Cardinal Laws (2012).

Hobsbawm, Eric John Ernest, Nations and Nationalism since 1780 (Cambridge University Press 1992).

Huntington, Samuel P, The Third Wave: Democratization in the Late Twentieth Century (1991).

Ionescu, Ghița and Ernest Gellner (eds), Populism: Its Meaning and National Characteristics (1969).

Kiss, É. Katalin, Anyanyelvünk állapotáról [On Our Mother Tongue] (Osiris 2004).

Kovács, András, Horváth, Anikó and Vidra, Zsuzsanna, 'The Ferry-Country between East and West: Debates on Modernity and Europe in Hungary' in Ichijo, Atsuko (ed) European Nations and Modernity (Palgrave MacMillan 2011) 158-82. 
Kováts, Eszter - Põim, Maari - Tánczos, Judit, Beyond Gender? Anti-gender Mobilization and the Lessons for Progressives, FEPS-PES Policy Brief 4 (2015).

Kováts, Eszter and Põim, Maari (eds.), Gender as Symbolic Glue: The Position and Role of Conservative and Far Right Parties Anti-gender Mobilizations in Europe (Friedrich Ebert Stiftung 2015).

Kriesi, Hanspeter and Pappas, Takis, 'Populism in Europe during Crisis: An Introduction' in Kriesi, Hanspeter and Pappas, Takis S. (eds) European Populism in the Shadow of Great Recession (1st ed. 2015) 1-24.

Laclau, Ernesto, 'Peronism in Historical and Comparative Perspective' in Archetti, Eduardo Cammack, Paul and Roberts, Bryan (eds) Sociology of the 'Developnig Countries': Latin America (1987) 137-47.

Levitsky, Steven and Way, Lucan, Competitive Authoritarianism (2010).

Melegh, Attila, On the East/West Slope: Globalization, Nationalism, Racism and Discources on Eastern Europe (Central European University Press 2006).

Niederberger, Andreas - Schink, Philipp (eds.) Republican Democracy: Liberty, Law and Politics (Edinburgh University Press 2013).

Osvát, Krisztina - Osvát, Szabolcs, 'Hungary's 2011 Constitution: Key Features and Political Background' (2011) ANU Centre for European Studies Briefing Paper Series 1-17.

Pettit, Philip, On the People's Terms: A Republican Theory and Model of Democracy (Cambridge University Press 2013).

Pogonyi, Szabolcs, 'Transborder Kin-minority as Symbolic Resource in Hungary' (2015) 4 Journal on Ethnopolitics and Minority Issues in Europe 73-98.

Rupnik, Jacques - Zielonka, Jan, 'Introduction: The State of Democracy 20 Years on. Domestic and External Factors' (2013) 27 East European Politics and Societies 3-25.

Shevtsova, Liliia Fedorovna, 'Can Electoral Autocracy Survive?' (2000) 11 Journal of Democracy $36-38$.

Shils, Edward, The Torment of Secrecy: The Background and Consequences of American Secruity Policies (Ivan R. Dee 1956).

Smith, Anthony, 'Culture, Community and Territory: The Politics of Ethnicity and Nationalism' (1996) 72 International Affairs 445-58.

Smith, Anthony, 'Ethnic Election and National Destiny: Some Religious Origins of Nationalist Ideals' (1999) 5 Nations and Nationalism 331-55.

Smith, Anthony, Ethno-Symbolism and Nationalism: A Cultural Approach (Routledge 2009).

Szelényi Iván and Csillag, Tamás, 'Drifting from Liberal Democracy: Traditionalist/Neoconservative Ideology of Managed Illiberal Democratic Capitalism in Post-communist Europe' (2015) 1 East European Journal of Society and Politics 18-48.

Takács, Péter, A rózsa neve: Magyar Köztársaság - Az államok nevéröl és a magyar állam átnevezéséröl (The Name of the Rose - On the Name of the States and The Renaming of Hungary) (Gondolat 2015).

The Fundamental Law of Hungary (25 April 2011).

Urbinati, Nadia, Democracy Disfigured: Opinion, Truth, and the People (Harvard University Press 2014).

Vámos and others v. Hungary, App. No. 19398/11 (Nov. 17, 2016)

Vidra, Zsuzsa, Horváth, Anikó and Fox, John, 'Tolerance and Cultural Diversity Discourses in Hungary' in Zapata-Barrero, Ricard and Triandafyllidou, Anna (eds) Addressing Tolerance and Diversity Discourses in Europe: Comparative Overview of 16 European Countries (2012) 31743.

Vidra, Zsuzsa and Fox, John, 'Mainstreaming of Racist Anti-Roma Discourses in the Media in Hungary' (2014) 12 Journal of Immigrant and Refugee Studies 437-55.

Wenman, Mark, Agonistic Democracy: Constituent Power in the Era of Globalisation (Cambridge University Press 2013).

Wodak, Ruth, KhosraviNik, Majid and Mral, Brigitte, Right-Wing Populism in Europe: Politics and Discourse (Bloomsbury Academic 2013). 
Wodak, Ruth, 'Critical discourse analysis: history, agenda, theory, and methodology' in Wodak, Ruth and Meyer, Michael (eds) Methods for Critical Discourse Analysis (SAGE Publications 2009) $1-33$.

Zakaria, Fareed, 'The Rise of Illiberal Democracy' (1997) 76 Foreign Affairs 22-43.

\section{LINKS}

1. A munkaalapú állam korszaka következik. Orbán Viktor beszéde a XXV. Bálványosi Nyári Szabadegyetem és Diáktáborban 2014. július 26. Tusnádfürdő (Băile Tuşnad) [The Age of the Work-Based State Has Come. The Speech of Viktor Orbán at the 25th Summer Open University and Student Camp of Bálványos 26 July 2014 Tusnádfürdő (Băile Tuşnad) (July 28, 2014), $<$ http://www.kormany.hu/hu/a-miniszterelnok/beszedek-publikaciok-interjuk/a-munkaalapuallam-korszaka-kovetkezik > <http://www.kormany.hu/en/the-prime-minister/the-prime-ministers-speeches/prime-minister-viktor-orban-s-speech-at-the-25th-balvanyos-summer-free-universityand-student-camp> accessed 1 November 2017.

2. A Nemzeti Hitvallás szövege [Text of the National Avowal], Fidesz.hu (April 18, 2011), <http:// www.fidesz.hu/hirek/2011-04-18/a-nemzeti-hitvallas-szovege/> accessed 15 February 2018.

3. Amnesty.org, Hungary: New law poses existential threat to NGOs (Febr. 14, 2018), <https:// www.amnesty.org/en/latest/news/2018/02/hungary-new-law-poses-existential-threat-to-ngos/> accessed 16 February 2018.

4. Baka v. Hungary, App. No. 20261/12 (June 23, 2016), <https://hudoc.echr.coe.int/> accessed 30 June 2016.

5. Case C-288/12, European Commission v Hungary (April 8, 2014), <http://curia.europa.eu/> accessed 30 April 2018.

6. Freedom House, Nations in Transit 2015: Hungary (2015), <https://freedomhouse.org/report/ nations-transit/2015/hungary> accessed 2 February 2016.

7. Halmai, Gábor - Scheppele, Kim Lane (eds.), Amicus Brief for the Venice Commission on the Fourth Amendment to the Fundamental Law of Hungary 15 (2013), <http://fundamentum.hu/ sites/default/files/amicus_brief_on_the fourth_amendment.pdf $>$ accessed 1 November 2017.

8. Halmai, Gábor, Towards an illiberal democracy, Eurozine (Jan. 25, 2012), <https://www. eurozine.com/towards-an-illiberal-democracy/> accessed 1 June 2016.

9. Haraszti, Miklos, The 'real' Viktor Orbán, OpenDemocracy, May 2, 2002, <https://www. opendemocracy.net/democracy-newright/article_358.jsp> accessed 1 June 2017.

10. HCLU (Hungarian Civil Liberties Union), EKI (Eötvös Károly Institute) and HHC (Hungarian Helsinki Committee), Assessing the First Wave of Legislation by Hungary's New Parliament (July 27, 2010), <https://tasz.hu/node/1486> accessed 1 June 2017.

11. <http://www.nefmi.gov.hu/political-declaration> accessed 1 June 2017.

12. <http://www.parlament.hu/irom39/00047/00047 e.pd.> accessed 1 June 2017.

13. Hungarian Spectrum.org, Orbán's proclamation of national cooperation on every wall (July 3, 2010), <http://hungarianspectrum.org/2010/07/03/orbans-proclamation-of-national-cooperationon-every-wall/> accessed 1 June 2017.

14. Hungary passes bill targeting Central European University (April 4, 2017), <http://www.bbc. com/news/world-europe-39493758> accessed 6 April 2017.

15. Karacsonygergely.blog.hu, Választási matematika haladóknak [Electoral Mathematics in Advanced Level] (Febr. 27, 2012), <http://karacsonygergely.blog.hu/2012/02/27/valasztasi matematika haladoknak> accessed 1 March 2012.

16. Kornai, János, Hungary's U-Turn, 10 Capitalism and Society (2015); János Kornai, Hungary's U-Turn, Expanded Version, $12<\mathrm{http} / / / w w w . k o r n a i-j a n o s . h u / K o r n a i \_H u n g a r y ' s \% 20 U-T u r n \% 20$ -\%20full.pdf $>$ accessed 1 June 2016.

17. Krekó, Péter, Fidesz \& hubris, The Budapest Times (July 12, 2010), <http://budapesttimesarchiv.bzt.hu/2010/07/12/fidesz-hubrisz/> accessed 15 July 2010.

18. Mudde, Cas, Is Hungary run by the radical right?, The Washington Post (August 20, 2015), $<$ https://www.washingtonpost.com/news/monkey-cage/wp/2015/08/10/is-hungary-run-by-theradical-right/?utm_term=.eb07e1eb6f19> accessed 10 September 2015. 
19. Petö, Andrea - Vasali, Zoltán, The 'laboratory' called Hungary: a challenge for understanding protest movements, OpenDemocracy (Jan 20, 2014), <https://www.opendemocracy.net/caneurope-make-it/andrea-pet $\% \mathrm{C} 5 \% 91$-zolt $\% \mathrm{C} 3 \% \mathrm{~A} 1$ n-vasali/\%E2\%80\%98laboratory\%E2\%80 \%99-called-hungary-challenge-for-understanding> accessed 30 January 2014.

20. Rácz, András, Multi-vectorialism failing? The Russia-policy of the Orbán-government, 15 Russkii vopros (2015), <http://www.russkiivopros.com/ruskii_vopros.php?pag=one\&id=619\&ka $\mathrm{t}=7 \& \mathrm{csl}=69>$ accessed 1 June 2016.

21. Scheppele, Kim Lane, Hungary, Misunderstood?, The New York Times (Jan. 21, 2012), <https:// krugman.blogs.nytimes.com/2012/01/21/hungary-misunderstood/> accessed 2 February 2012.

22. Scheppele, Kim Lane, Hungary's Constitutional Revolution, The New York Times (Dec. 19. 2011), <https://krugman.blogs.nytimes.com/2011/12/19/hungarys-constitutional-revolution/> accessed 15 December 2011.

23. Shafir, Michael, The Politics of Public Space and the Legacy of the Holocaust in Postcommunist Hungary, Part 3. Viktor Orban's ,Transfiguration' or the Making of a Radical Conservative, 6 RFE/RL East European Perspectives (2004), <http://www.rferl.org/reports/eepreport/2004/ 06/13-230604.asp> accessed 4 June 2017.

24. Simon, Zoltan, Hungary on Path to Shed Junk Grade and Shield Forint, Orban Says, Bloomberg, Dec. 15, 2014, <https://www.bloomberg.com/news/articles/2014-12-15/hungary-on-path-toshed-junk-grade-and-shield-forint-orban-says $>$ accessed 7 May 2015.

25. Szigetvári, Viktor - Tordai, Csaba - Vető, Balázs, Beyond democracy - The model of the new Hungarian parliamentary electoral system (Part 2) (2011), <https://lapa.princeton.edu/hosteddocs/ hungary/Beyond\%20democracy\%20-\%2027\%20Nov\%202011.pdf> accessed 1 June 2016.

26. The Council of Europe's European Commission for Democracy through Law (Venice Commission) issued a special report on the case. See CDL-AD(2012)001-e, Opinion on Act CLXII of 2011 on the Legal Status and Remuneration of Judges and Act CLXI of 2011 on the Organisation and Administration of Courts of Hungary, adopted by the Venice Commission at its 90th Plenary Session (Venice, 16-17 March 2012), <http://www.venice.coe.int> accessed 4 June 2017.

27. Transindex.ro, Negyedmillióval csökkent tíz év alatt a magyarok száma a Kárpát-medencében (Dec. 7, 2010), <http://itthon.transindex.ro/?cikk=13124> accessed 5 January 2011. 